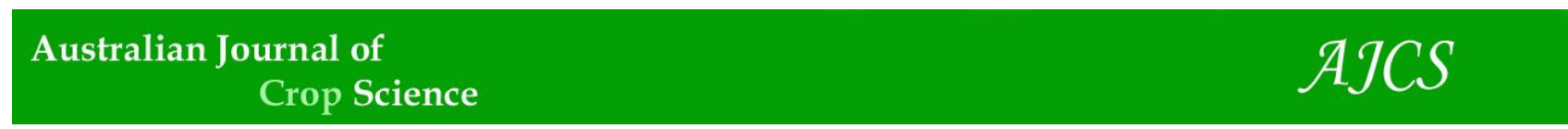

AJCS 11(09):1106-1115 (2017)

ISSN:1835-2707

doi: 10.21475/ajcs.17.11.09.pne517

\title{
Molecular variability and population structure of a core collection of date palm (Phoenix dactylifera L.) cultivars from Australia and the Middle East
}

\author{
Ahmed Al-Najm ${ }^{1,2}$, Shuming Luo ${ }^{1}$, Nabil M. Ahmad ${ }^{1 *}$, Mohammad Pourkheirandish ${ }^{1}$, Richard \\ Trethowan ${ }^{1}$
}

\author{
${ }^{1}$ Plant Breeding Institute, Faculty of Agriculture and Environment, University of Sydney, 107 Cobbitty Road, \\ Cobbitty, NSW 2570, Australia \\ ${ }^{2}$ University of Basrah, Date palm research center, Basrah, Iraq
}

*Corresponding authors: nabil.ahmad@sydney.edu.au; nabeeldeeb@yahoo.com

\begin{abstract}
Understanding genetic relatedness in date palm (Phoenix dactylifera L.) germplasm is important for effective plant improvement. Microsatellite (SSR) markers were used to assess the molecular variation and population structure of 60 Australian locally selected and exotic genotypes ( 24 female, 30 male and 6 related species), 12 Iraqi female cultivars and 10 female cultivars from Jordan. The main objectives were to survey genetic diversity and determine population structure in this core date palm collection which includes the most important and widely distributed cultivars in Australia. These Australian accessions were then compared to those originating from the date palm center of origin in the Middle East. PCR of 17 SSR primers (co-dominant markers) produced a total of 313 alleles ranging from 5 to 31 with an average of 18.4 alleles per locus. The PIC value for these 17 primers ranged from 0.4771 to 0.8199 with a mean of 0.670 . The mean expected heterozygosity (0.841), mean observed heterozygosity (0.946) and Shannon's information index (2.067) indicated a high level of genetic diversity among the accessions. Multi-locus DNA fingerprints based on the 17 SSR loci unambiguously differentiated all accessions and revealed an absence of duplicated samples. Ordination and cluster analyses showed that the Australian accessions did not group together geographically; instead separate male and female groups differentiated among the six clusters. A Bayesian cluster analysis also partitioned the accessions into six groups and this result was largely compatible with the result of ordination analysis. The Australian date palm germplasm is highly diverse and thus provides an effective platform for plant improvement, enhancement of date production and the conservation of genetic resources.
\end{abstract}

Keywords: genetic diversity, germplasm, plant breeding, population structure.

Abbreviations: AFLP_amplified fragment length polymorphism, iPBS_inter-primer binding site, ISSR_inter-simple sequence repeat, PCoA_principal coordinate analysis, RAPD_random amplified polymorphic DNA, RFLP_Restriction fragment length polymorphisms, SSR_simple sequence repeat, UPGMA_unweighted pair group method with arithmetic mean.

\section{Introduction}

Date palm (Phoenix dactylifera $\mathrm{L}$.) is a long-lived, dioecious and monocotyledonous fruit plant $(2 \mathrm{n}=36)$ belonging to family Arecaceae (Coryphoideae) (Allen, 1910; Barrow, 1998). There are 14 species in the genus Phoenix of which two are related to date palm ( $P$. theophrastii Greuter, and $P$. sylvestris (L.) Roxb) (Barrow, 1998; Rivera et al., 2008). Dates are one of the world's oldest cultivated fruits and date palm was domesticated in Mesopotamia (now Iraq) more than 5,000 years ago (Barrow, 1998; Barrow, 1999; Hamza et al., 2011; Osman, 1984; Wrigley, 1995). Date palm was traditionally grown in the arid regions of Africa, the Middle East and South Asia (Elmeer et al., 2011; Khan and Bi, 2012). However, the tolerance of date palm to high temperature, drought and salinity (Elsafi, 2012; Elshibli and Korpelainen, 2010) led to the introduction of date palm to other regions including northern Iran, eastern China, northern India, USA, sub-tropical South America, South Africa and Australia (Arabnezhad et al., 2012; McCubbin, 2007; Nixon, 1951; Zaid and de Wet, 2002). The dissemination of date palm around the Mediterranean coast in ancient times was driven by the exchange of vegetative materials, seeds and pollen (Mahmud, 1958). Today, the trade in dates is steadily rising and demand is increasing on all five inhabited continents. According to FAOSTAT (2012), the harvested area of dates was estimated to be 1.11 million hectares in over 40 countries, with an annual production of 7.5 million tonnes. The number of date palm cultivars globally is thought to be as high as 5,000 (Bashah, 1996; Jaradat and Zaid 2004). There are reported to be 650 cultivars in Iraq (Ibrahim, 2008), 340 in Saudi Arabia (Al-Mssallem, 1996) and 135 in the United Arab Emirates (Ghaleb, 2008). Morphological characterization has identified more than 220 clonally propagated cultivars in Morocco (Toutain, 1972), 140 in Tunisia, 450 in Saudi Arabia, 400 in Sudan, 1,000 in Algeria (Al-Khalifah and Askari 2003), over 300 in Pakistan and more than 200 in the Sultanate of Oman (Al-Yahyai and AlKhanjari, 2008). The introduction of date palms in Australia commenced in the 1890 s by cameleers and well-established populations commonly exist around isolated springs and waterholes on outback transportation routes (McColl, 1992; 
Petherbridge, 1980). Related species such as $P$. canariensis Chabaud, $P$. reclinata Jacq. and $P$. roebelenii O'Brien, were also introduced into Australia around that time. Despite the long heritage of successful date palm establishment in Australia, the annual consumption of 5,000 to 7,000 tonnes depends almost exclusively on imports (Reilly et al., 2010). Many areas of Australia have long hot-dry summers with minimal rainfall that are suitable for date palm cultivation (Petherbridge, 1980; Shabani et al., 2012). Production is currently concentrated in central Australia, Western Australia, South Australia and in the Cunnamulla-Eulo areas of western Queensland (Kenna and Mansfield, 1997; McColl, 1992; Reilly et al., 2010; Shabani et al., 2012).

Furthermore, climate change can impact date production if growing conditions change, particularly temperature and precipitation (Shabani et al., 2012). While lower temperatures and higher rainfall might limit date production in some traditional areas, it is likely that date palm plantations could extend further south in South Australia and further east in south-eastern Australia. In the original date-producing countries such as the Kingdom of Saudi Arabia, each female cultivar has a specific male selection as the pollinator since the effect of the pollen source can influence the physical and chemical characteristics of the fruit. However, to the knowledge of the authors, no female and male combinations have been optimized in Australian commercial date production and farmers instead use mixed pollen to fertilizer female trees (Kenna and Mansfield, 1997). Mixed pollination tends to result in variable fruit and seed size (xenia) and uneven fruit ripening caused by metaxenia (Ahmad and Ali, 1960; Shafique et al., 2011). Al-Najm et al. (2016) concluded that the Australian date palm germplasm is genetically diverse for both female and male cultivars. Therefore, optimizing specific male and female cultivar combinations to increase productivity and quality should be possible and this is a significant priority for the Australian date industry.

Intra-cultivar variation can potentially cause confusion in cultivar nomenclature, preservation and utilization (Trifi et al., 2000; Zaid and de Wet, 2002). The introduction of new germplasm from neighbouring countries and traditional hand pollination can generate recombinant genotypes that may extend the adaptation of date palm. Therefore, knowledge of date palm genetic diversity at the regional level in Australia can provide a basis for the genetic improvement and maintenance of date palm germplasm (Akkak et al., 2009; AlNajm et al., 2016; Arabnezhad et al., 2012).

Date palm is long-lived, vegetatively propagated through offshoots or tissue culture and a unique for the study of genetic diversity. Traditionally, genetic diversity analysis of date palm used morphological markers based on a few characteristics of the fruit (shape, weight, colour, skin aspect, consistency and texture), leaves and spines and pedigree information. However, analysis among closely related cultivars using morphological characters alone is often unreliable and influenced by the environment (Mehmood et al., 2013; Luo et al., 2015; Borna et al., 2016). Isozyme markers were used as an alternative, although the method was limited by the number of informative data and gave no direct assessment of DNA genomic variation (see Akbari et al. 2012; Al-Najm et al., 2016; Khanam et al., 2012; Mehmood et al., 2014; Mehmood et al., 2016; 2014; Sedra et al., 1993; Sedra et al., 1996).

According to Al-Dous et al. (2011), the genome size of date palm $(2 \mathrm{n}=36)$ is approximately 658-Mbp. Restriction fragment length polymorphisms (RFLP) were used for date palm cultivar identification (Corniquel and Mercier, 1994), however the technique was considered laborious and unsuitable for studying large numbers of samples. Other molecular markers including random amplified polymorphic DNA (RAPD) (Sedra et al., 1998; Soliman et al., 2003; Williams et al., 1990), inter simple sequence repeats (ISSR) (Hamza et al., 2013; Hamza et al., 2012), amplified fragment length polymorphism (AFLP) (Al-Khalifah and Askari, 2003; Cao and Chao, 2002; El-assar et al., 2005; Elassar et al., 2003); simple sequence repeat (SSR) (Ahmed and AlQaradawi, 2009; Al-Ruqaishi et al., 2008; Elsafi, 2012; Elshibli and Korpelainen, 2008; Pintaud et al., 2010; Zehdi et al., 2004; Zehdi et al., 2012; Zehdi-Azouzi et al., 2015; Zehdi-Azouzi et al., 2016), chloroplast DNA analysis (Sakka et al., 2013; Rhouma-Chatti et al., 2014) and inter-primer binding site (iPBS) (Al-Najm et al., 2016) were used to assess the genetic diversity of date palm germplasm collected from a variety of countries. Other researchers used a combination of these marker systems to study the genetic diversity of date palm germplasm (Abdulla and Gamal, 2010; Adawy et al., 2005; Hussein et al., 2005; Saker et al., 2006; Saker et al., 2000). The objective of this study was to (i) assess the genetic variation of exotic and locally selected Australian date palm cultivars, (ii) compare the genetic relatedness of Australian and Middle Eastern germplasm, (iii) estimate potential male/female compatibility and (iv) compare the clonal fidelity of cultivars derived from tissue culture with the same cultivars propagated from offshoots of the original plant.

\section{Results}

\section{Genome variation among the date palm collection using} SSR markers

All 17 SSRs tested generated PCR amplifications and polymorphisms among the 82 selected date palm accessions were detected. The wild relatives namely, $P$. canariensis, $P$. reclinata, $P$. roebelenii, and $P$. theophrasti were included in this study because they are cross compatible with Phoenix dactylifera and fertile hybrid offspring can be produced that have implications for palm improvement (Gros-Balthazard, 2013). The information from these 17 primers, including the number of alleles and mean PIC values, are included in supplementary Table 2. A total of 313 alleles were generated across the 17 loci and numbers of alleles ranged 5 to 31 with an average of 18.4, indicating a high degree of allelic polymorphism. Primer PDCAT1 produced the highest number of bands (31) and primer PDCAT3 generated the lowest (5). Primer PDCAT4 had the highest PIC value (0.8199) whereas primer mPdCIR070 had the lowest (0.4771). The SSR fingerprinting pattern of the 82 accessions from primer PDCA2 are shown in Figure 1. The number of unique banding patterns among the 82 accessions validated the use of SSR markers for the identification of date palm DNA. The SSR marker system can therefore be used to assess a wide range of genomic DNA diversity in date palm and related species.

Summary statistics for each of the five groups of accessions (AF: Australian female, AM: Australian male, IR: Iraqi female, JO: Jordanian female and SP: related species) covering the number of different alleles, number of effective alleles, Shannon's information index, observed heterozygosity, expected heterozygosity, unbiased expected heterozygosity and fixation Index are listed in Table 1. Expected heterozygosity (He) ranged from 0.820 (SP) to 0.868 (AM), with an average of 0.841 , whereas unbiased expected heterozygosity $(\mathrm{uHe})$ ranged from $0.870(\mathrm{JO})$ to 0.917 (SP) with an average of 0.883. The Shannon's 
information index among the five groups ranged from 1.811 (SP) to 2.332 (AM), with an average of 2.067. Nei's (1972) pairwise population matrix of the genetic identity among all five groups is listed in Table 2. The highest genetic identity (0.952) existed between the Jordanian female collections and related species whereas the lowest genetic identity (0.119) was observed between Australian female accessions and Australian male collections.

The principal coordinate analysis, summarized in a spatial representation of the relative genetic distances among the individual accessions, revealed five groups of date palm accessions (Figure 2). The plane of the first three PCoA axes accounted for $34.11 \%$ of the total variation (first axis = $15.26 \%$, second $=10.11 \%$, third $=8.74 \%$ ). Most of the Australian female and male accessions were clustered as a large group distributed to the right of the plane and the lower plane. The second large group, including five accessions of the related species, was clustered as a small group near the right of the axis. A third group clustered in the upper plane and included all the Iraqi and Jordanian cultivars. Within this group, the Iraqi accessions mainly clustered in the upper left plane, whereas the Jordanian cultivars had a wider spread.

\section{Phylogenetic relationship and genetic structure of the core collection}

The dendrogram produced using the un-weighted pair group method with arithmetic means (UPGMA), placed the 82 accessions into six major clusters (Figure 3), further supporting the results of the principal coordinate analysis. The first cluster comprised 33 female cultivars including 15 from Australia, 11 from Iraq and 7 from Jordan. The second cluster included 23 Australian male accessions. The third cluster comprised two accessions of $P$. theophrasti, three female Medjool cultivars (Jordanian Medjool originated from offshoot, Australian Medjool propagated through tissue culture and Australian Medjool coded AD2 originated from offshoot), five Australian male accessions and seven Australian female cultivars. The fourth cluster included two Australian female cultivars (AD1, AD3), one Iraqi female cultivar (Kastawi) and two Jordanian female cultivars (Bofakoos, Zaghloul). The fifth cluster contained one Australian female cultivar (Baskary) and two Australian male accessions (16-27, Jarvis). The sixth cluster comprised the three related species $P$. roebelenii, $P$. canariensis, and $P$. reclinata. While the dendrogram comprised six main clusters, some clusters contained a number of sub-groups.

Population stratification of the accessions based on $\Delta K$ values computed by STRUCTURE HARVESTER revealed six clusters as the most probable number of K (Evanno et al., 2005) (Figure 4). The optimal number of genetic clusters in these 82 accessions was determined to be six (Kopt=6, Figure 5). The overall partition was partially in agreement with principal coordinate analysis (Figure 2) and the dendrogram in Figure 3. The first cluster comprised 20 exotic female cultivars collected from Australia and two accessions of $P$. theophrasti. The second cluster contained 28 Australian male accessions and the third cluster all 12 Iraqi female cultivars. The fourth cluster comprised five Jordanian female cultivars, three exotic female cultivars collected from Australia and two Australian male genotypes. The fifth comprised five female cultivars from Jordan and the last cluster the three related species.

All 17 SSR loci were analyzed for amplification in five wild palm accessions; $P$. canariensis $(1), P$. reclinata (1), $P$. roebelenii (1), and $P$. theophrasti (2). Primer mPdCIR050 did not amplify in the expected allele range in $P$. reclinata whereas eight primers showed products outside the allele range. Seven primers generated no amplifications in $P$. theophrasti, and no individual primer was outside the allele range amplifications in this species. Primers PDCAT1 and PDCAT4 did not amplify in the expected allele range in $P$. canariensis, and four primers produced products outside the allele range. Primer mPdCIR063 generated no product in $P$. roebelenii; however four primers showed products outside the allele range (Table 3 ).

\section{Discussion}

Date palm breeding is challenging because of the long juvenility and dioecity of the species (Khanam et al., 2012). Accurate identification of accessions in a germplasm collection is an important first step in crop improvement. Molecular marker systems, including SSRs, can more accurately differentiate germpalsm than methods based on morphological traits or isoenzymes because they are objective, reproducible and independent of environmental influences (Al-Najm et al., 2016; Mehmood et al., 2016). In the current study, seventeen polymorphic SSR markers discriminated a range of Phoenix dactylifera accessions including related species and provided valuable information on the genetic relationship amongst the accessions.

The SSR marker system also distinguished three wild species ( $P$. canariensis, $P$. reclinata and $P$. roebelenii) from the $P$. dactylifera and $P$. theophrasti accessions. Within $P$. dactylifera, the SSR system further separated the cultivated date palm accessions into clusters according to locality and sexuality. The clustering of accessions collected from the same geographical region, despite the widespread distribution of date palm in the tropical and sub-tropical world and more than 120 years of cultivation in Australia, suggested that germplasm exchange among regions has been limited. Furthermore, only a small number of date palm cultivars evaluated in this study have ever been used in breeding (AlNajm et al., 2016).

The 313 alleles obtained from 17 primers were far more than reported by Elshibli and Korpelainen (2009) and Elsafi (2012) who used microsatellite markers on date palm germplasm from the northern region of Sudan. . The vast genetic diversity detected in the Australian date palm germplasm suggests that early introductions came from a broad range of countries in the Middle East, North Africa and the USA.

The co-dominant SSR primers used in this study were developed specifically for the date palm species (Akkak et al., 2009; Billotte et al., 2004). They were polymorphic and evenly distributed across the genome, required minimal amounts of DNA and distinguished genetic differences. According to the PIC results calculated from the 17 SSR primers, only one primer (mPdCIR070) had a PIC value under 0.5 , whereas the other 16 primers were very informative. However, the main drawback of the SSR method is the cost of designing species-specific primers (Wünsch, 2009; Odong et al., 2011).

Elsafi (2012) reported a Shannon's Information Index of 1.78 , expected heterozygosity of 0.8 and unbiased expected heterozygosity of 0.82 . Similar average values were observed in the current study for the Shannon's Information Index (2.067), expected heterozygosity (0.841) and unbiased expected heterozygosity (0.883). Therefore crosscompatibility is a function of parental genetic distance. Cross-incompatibility hinders the creation of agriculturally useful hybrids from parental clones (Elshibli and Korpelainen, 2009). It is likely that controlled hybridization 
Table 1. Summary statistics for 82 date palm (Phoenix dactylifera) accessions assessed with 17 SSR primers.

\begin{tabular}{lcccccccc}
\hline Groups & $\mathrm{N}$ & $\mathrm{Na}$ & $\mathrm{Ne}$ & $\mathrm{I}$ & $\mathrm{Ho}$ & $\mathrm{He}$ & $\mathrm{uHe}$ & $\mathrm{F}$ \\
\hline AF & 25.000 & 12.471 & 9.153 & 2.227 & 0.918 & 0.854 & 0.871 & -0.081 \\
AM & 30.000 & 14.412 & 9.632 & 2.332 & 0.923 & 0.868 & 0.882 & -0.076 \\
IR & 12.000 & 9.765 & 7.447 & 2.036 & 0.966 & 0.836 & 0.872 & -0.179 \\
JO & 10.000 & 8.471 & 6.459 & 1.931 & 0.947 & 0.826 & 0.870 & -0.150 \\
SP & 5.000 & 6.706 & 6.139 & 1.811 & 0.976 & 0.820 & 0.917 & -0.194 \\
\hline Mean & 16.000 & 10.365 & 7.766 & 2.067 & 0.946 & 0.841 & 0.883 & -0.136 \\
\hline
\end{tabular}

$\mathrm{N}$, number of sample size; Na, number of different alleles; Ne, number of effective alleles; I, Shannon's information index; HO, Observed Heterozygosity; He, expected heterozygosity; uHe, unbiased expected heterozygosity; F, Fixation Index; AF, Australian female collections; AM, Australian male collections; IR, Iraqi female cultivars; JO, Jordan female collections; SP, Other species.

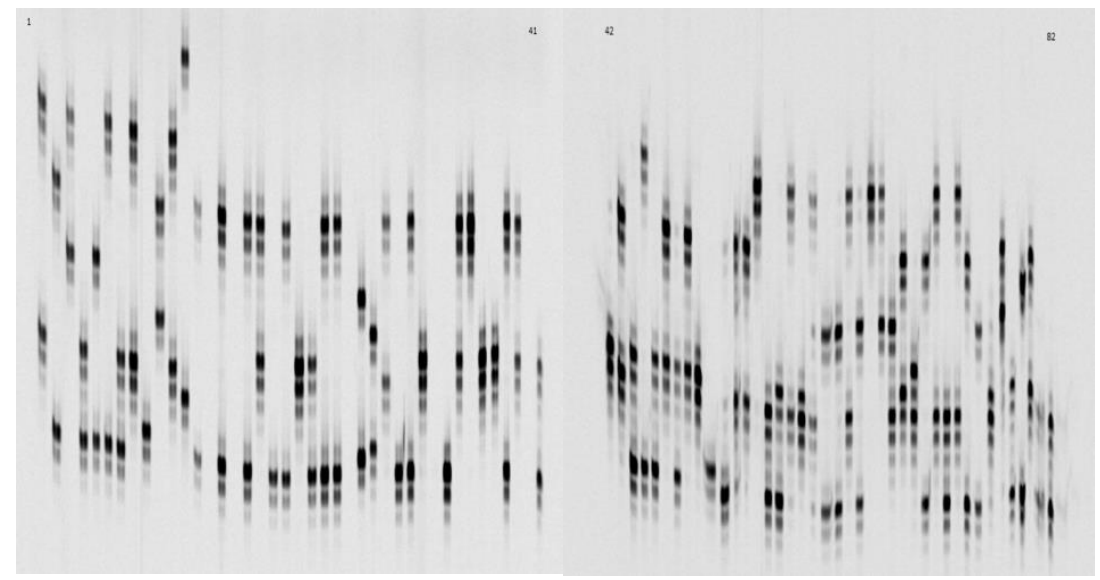

Fig 1. SSR PCR banding patterns for 82 DNA accessions generated from primer PDCAT2. The forward primer was 5 - tailed with the 19 base pair M13 sequence (CACGACGTTGTAAAACGAC). Accessions 1-41 used IRDye 700 and accessions 42-82 used IRDye 800. Identification of accessions is listed in Supplementary Table 1.

Table 2. Pairwise population matrix of Nei genetic identity.

\begin{tabular}{|c|c|c|c|c|c|}
\hline & $\mathrm{AF}$ & $\mathrm{AM}$ & IR & $\mathrm{JO}$ & SP \\
\hline $\mathrm{AF}$ & 0.000 & & & & \\
\hline $\mathrm{AM}$ & 0.119 & 0.000 & & & \\
\hline IR & 0.493 & 0.425 & 0.000 & & \\
\hline JO & 0.343 & 0.391 & 0.365 & 0.000 & \\
\hline SP & 0.760 & 0.764 & 1.017 & 0.952 & 0.000 \\
\hline
\end{tabular}

AF, Australian female collections; AM, Australian male collections; IR, Iraqi female cultivars; JO, Jordan female collections; SP, Other species

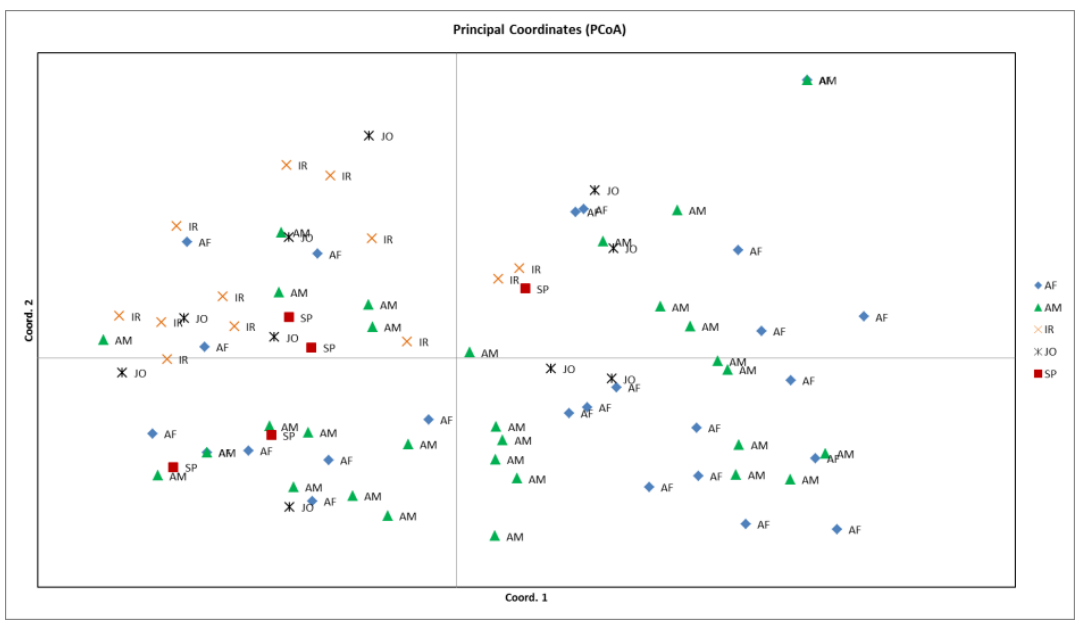

Fig 2. Principle coordinate analysis of 82 date palm accessions with 17 SSR primers. AF, Australian female collections; AM, Australian male collections; IR, Iraqi female cultivars; JO, Jordan female collections; SP, Other species. 
Table 3. Cross-species transferability of 17 SSR primers.

\begin{tabular}{lcccc}
\hline SSR primers & $\begin{array}{c}\text { P. reclinata } \\
\text { EAR/OAR }\end{array}$ & $\begin{array}{c}\text { P. theophrasti } \\
\text { EAR/OAR }\end{array}$ & $\begin{array}{c}\text { P. canariensis } \\
\text { EAR/OAR }\end{array}$ & $\begin{array}{c}\text { P. roebelenii } \\
\text { EAR/OAR }\end{array}$ \\
\hline mPdCIR015 & $\mathrm{Y} / \mathrm{Y}$ & $\mathrm{Y} / \mathrm{N}$ & $\mathrm{Y} / \mathrm{Y}$ & $\mathrm{Y} / \mathrm{Y}$ \\
mPdCIR016 & $\mathrm{Y} / \mathrm{Y}$ & $\mathrm{Y} / \mathrm{N}$ & $\mathrm{Y} / \mathrm{Y}$ & $\mathrm{Y} / \mathrm{N}$ \\
mPdCIR025 & $\mathrm{Y} / \mathrm{N}$ & $\mathrm{Y} / \mathrm{N}$ & $\mathrm{Y} / \mathrm{N}$ & $\mathrm{Y} / \mathrm{N}$ \\
mPdCIR032 & $\mathrm{Y} / \mathrm{N}$ & $\mathrm{Y} / \mathrm{N}$ & $\mathrm{Y} / \mathrm{N}$ & $\mathrm{Y} / \mathrm{N}$ \\
mPdCIR035 & $\mathrm{Y} / \mathrm{N}$ & $\mathrm{Y} / \mathrm{N}$ & $\mathrm{Y} / \mathrm{N}$ & $\mathrm{Y} / \mathrm{N}$ \\
mPdCIR048 & $\mathrm{Y} / \mathrm{Y}$ & $\mathrm{Y} / \mathrm{N}$ & $\mathrm{Y} / \mathrm{N}$ & $\mathrm{Y} / \mathrm{N}$ \\
mPdCIR050 & $\mathrm{N} / \mathrm{N}$ & $\mathrm{Y} / \mathrm{N}$ & $\mathrm{Y} / \mathrm{Y}$ & $\mathrm{N} / \mathrm{N}$ \\
mPdCIR063 & $\mathrm{Y} / \mathrm{N}$ & $\mathrm{N} / \mathrm{N}$ & $\mathrm{Y} / \mathrm{N}$ & $\mathrm{Y} / \mathrm{N}$ \\
mPdCIR070 & $\mathrm{Y} / \mathrm{N}$ & $\mathrm{N} / \mathrm{N}$ & $\mathrm{Y} / \mathrm{N}$ & $\mathrm{Y} / \mathrm{Y}$ \\
mPdCIR078 & $\mathrm{Y} / \mathrm{Y}$ & $\mathrm{N} / \mathrm{N}$ & $\mathrm{Y} / \mathrm{N}$ & $\mathrm{Y} / \mathrm{N}$ \\
mPdCIR085 & $\mathrm{Y} / \mathrm{Y}$ & $\mathrm{Y} / \mathrm{N}$ & $\mathrm{Y} / \mathrm{N}$ & $\mathrm{Y} / \mathrm{Y}$ \\
mPdCIR090 & $\mathrm{Y} / \mathrm{N}$ & $\mathrm{N} / \mathrm{N}$ & $\mathrm{Y} / \mathrm{N}$ & $\mathrm{Y} / \mathrm{N}$ \\
mPdCIR093 & $\mathrm{Y} / \mathrm{Y}$ & $\mathrm{N} / \mathrm{N}$ & $\mathrm{Y} / \mathrm{Y}$ & $\mathrm{Y} / \mathrm{N}$ \\
PDCAT1 & $\mathrm{Y} / \mathrm{N}$ & $\mathrm{Y} / \mathrm{N}$ & $\mathrm{N} / \mathrm{N}$ & $\mathrm{Y} / \mathrm{N}$ \\
PDCAT2 & $\mathrm{Y} / \mathrm{Y}$ & $\mathrm{N} / \mathrm{N}$ & $\mathrm{Y} / \mathrm{N}$ & $\mathrm{Y} / \mathrm{N}$ \\
PDCAT3 & $\mathrm{Y} / \mathrm{N}$ & $\mathrm{N} / \mathrm{N}$ & $\mathrm{Y} / \mathrm{N}$ & \\
PDCAT4 & $\mathrm{Y} / \mathrm{Y}$ & $\mathrm{Y} / \mathrm{N}$ & $\mathrm{N} / \mathrm{N}$ & \\
\hline E, expected allele rang. $\mathrm{OAR}$, outside allele range; $\mathrm{Y} / \mathrm{N}$, yes/no & &
\end{tabular}

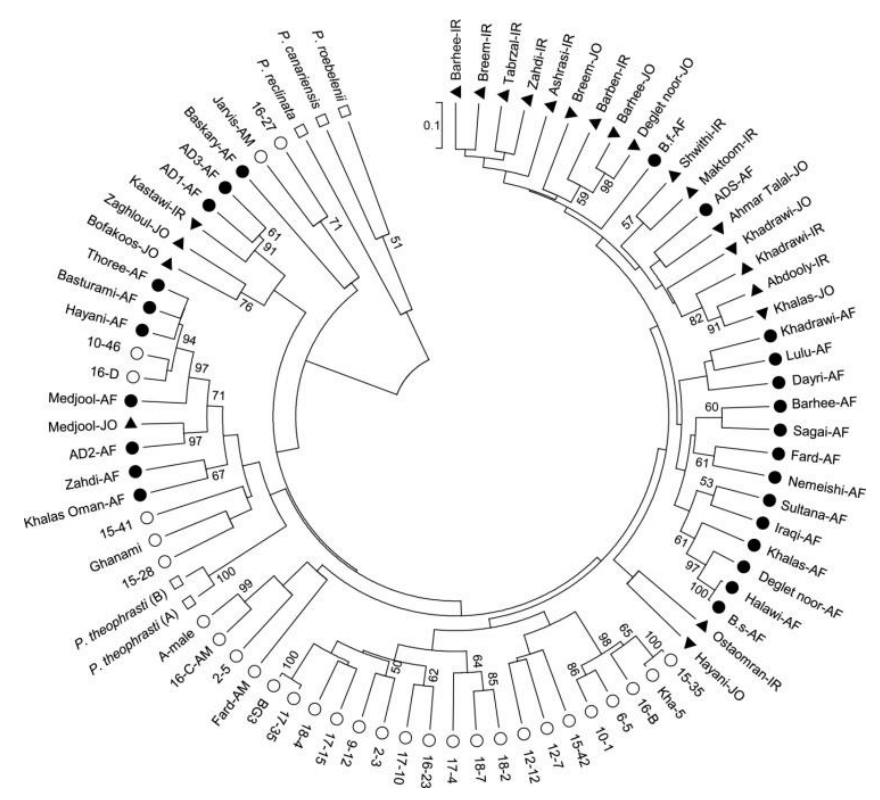

Fig 3. Dendrogram of 82 date palm accessions generated with data from 17 SSR primers showing six main clusters with some clusters containing sub-groups. $\operatorname{AF}(\bullet)$, Australian female collections; $\operatorname{AM}(\mathrm{O})$, Australian male collections; $\operatorname{IR}(\boldsymbol{\Delta})$, Iraqi female cultivars; $\operatorname{JO}(\boldsymbol{\nabla})$, Jordan female collections; $\mathrm{SP}(\square)$, other species including $P$. canariensis, $P$. reclinata, $P$. roebelenii, and $P$. theophrasti formed a paraphyletic outgroup. Local bootstrap values after 1000 replicates are indicated near the branches. Bootstrap value below $50 \%$ is not shown.

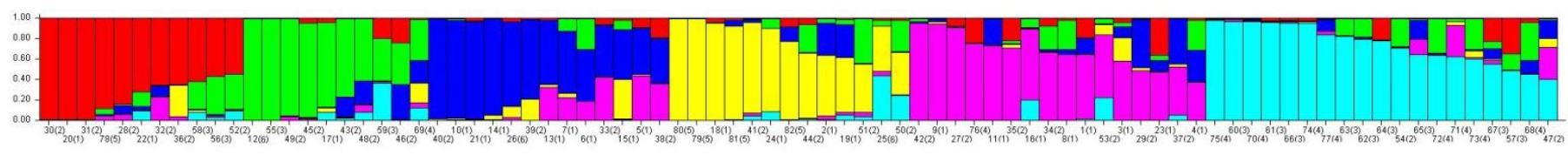

Fig 4. Model-based cluster construction using Bayesian analysis among 82 date palm accessions based on allelic variants at 17 SSR loci. Six clusters were defined using the Evanno et al. (2005) method. Each vertical line represents an individual multi-locus genotype. Each color represents the most likely ancestry of the cluster from which the genotype or partial genotype was derived. Individuals with multiple colours have admixed genotypes from multiple clusters. Accession numbers are listed in Supplementary Table 1 . 


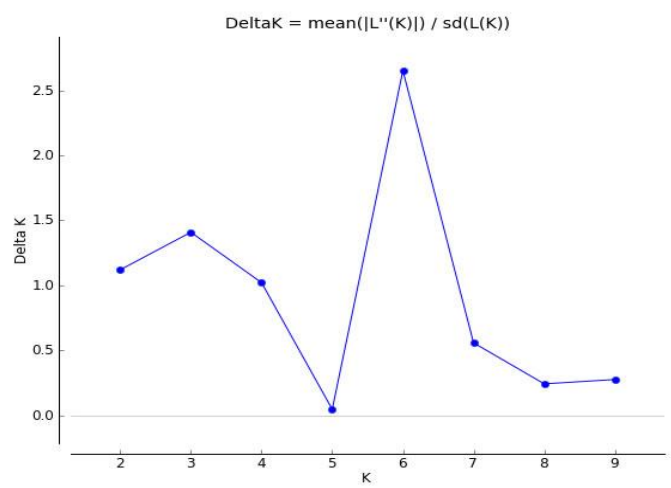

Fig 5. Plot of delta $K$ (filled circles, solid line) calculated as the mean of the second-order rate of change in likelihood of $K$ divided by the standard deviation of the likelihood of $K, \mathrm{~m}(|\mathrm{~L} "(K)|) / \mathrm{sd}[\mathrm{L}(K)]$. Delta $\mathrm{K}$ is the potential number of genetic clusters that may exist in the overall sample of individuals.

between the most cross-compatible parents that maximize genetic distance will produce higher fruit yields and better date palm cultivars. However, Al-Najm et al. (2016) reported a much lower Shannon's Information Index (0.33), expected heterozygosity $(0.218)$ and unbiased expected heterozygosity (0.229) in Australian germplasm when using the dominant marker system iPBS. The dominance nature of the marker system used could have contributed to these differences as the final dendrogram generated from both the SSR (codominant) and the iPBS (dominant) methods revealed a very similar pattern of genetic relatedness in the germplasm. The Barhee and Khadrawi cultivars originated in Iraq and these cultivars when collected from Jordan clustered in the same sub-group as other Iraqi cultivars. However, the Barhee and Khadrawi cultivars were tissue culture-derived in Australia and they clustered in a different sub-group suggesting genetic drift or new genetic variation introduced from tissue culture. Our finding is similar to that of Elhoumaizi et al. (2006) who showed that the Moroccan cultivar Medjool, collected from different geographical regions, had a significant range of genetic variation. These observations suggest that targeted intra-varietal selection of major date cultivars such as Medjool, Barhee and Deglet Noor could be an effective crop improvement strategy (Al-Najm et al., 2016). Date palm breeding in Iraq is highly dependent upon seed propagation and subsequent selection based on specific characteristics important to local farmers such as fruit quality and plant vigor (Khierallah et al., 2011). Results indicated that cultivars collected from the Diyala area of Iraq and Deir Alla in Jordan were genetically similar. Consequently, it would be advantageous for Iraqi and Jordanian farmers to access cultivars from other districts to overcome the limitations of inbreeding arising from current practices (Al-Najm et al., 2016). Since recent Australian quarantine laws prohibit the introduction of date palm, the genetic variability of Australian dates cannot be enhanced through introduction. However, this study reveals that there is significant genetic diversity in the established Australian date germplasm. Crossing between genetically distant Australian cultivars could enhance hybrid vigour and this response could be fixed using asexual propagation and tissue culture. Specifically, among the Australian date palm accessions, two male (16-27, Javis) and three female (Baskary, AD1, AD3) accessions were genetically distant from the rest of the collections. To maximize the xenia and metaxenia effects, one of these cultivars should be used as a parent to widen parental genetic distance thus increasing the probability of identifying hybrids with increased quality and productivity (Al-Najm et al., 2016). Both Krueger (1995) and Barrow (1998) reported that species classification within the Phoenix genus was complicated by naturally occurring compatible interspecific hybridization. They indicated that $P$. theophrasti is genetically very closely related to $P$. dactylifera. Additionally, using SSR and ITS (internal transcribed spacer) marker systems, Rivera et al. (2008) differentiated date cultivars with multi interspecific characteristics derived from $P$. theophrasti, $P$. dactylifera and $P$. sylvestris. The SSR results from this study confirmed both the Barrow (1998) and Rivera et al. (2008) findings that $P$. dactylifera and $P$. theophrasti are not distinctly separate species. Nevertheless, more extensive morphological and molecular characterization of a larger number of accessions of $P$. dactylifera and $P$. theophrasti is required before the genetic relationship between these two species can be confirmed. The SSR marker system was also confirmed as an effective tool for exploring genetic diversity at the species level.

\section{Materials and methods}

\section{Plant materials}

The 82 accessions genotyped using the SSR marker system are listed in supplementary Table 1. Four were collected from the Royal Botanic Garden, Sydney. Fifty accessions including 23 females and 27 males were collected from the Desert Fruit Company (a date palm orchard near Alice Springs, Northern Territory, Australia). This orchard preserves the major date palm cultivars (and their derivatives) introduced into Australia from the Middle East, North Africa and the USA over the past 120 years. Six cultivars including 4 females and 2 males were collected from Riverland Date Garden, South Australia (a date palm orchard at 376 Gura Road, Gurra Gurra). Another 12 female cultivars were collected from the Diyala district of Iraq and 10 female cultivars from the Deir Alla district in Jordan. Several cultivars were duplicated by collecting germplasm from two or three locations. This provided a basis for evaluating genetic stability and the genetic implications of clonal propagation.

\section{DNA extraction and quantification}

Fresh young leaves were collected from the listed accessions and were used for DNA isolation. DNA was extracted from 
$200 \mathrm{mg}$ of fresh leaves using plant DNA isolation Mini Kit (Bioline, Australia) in accordance with the manufacturer's protocols. The quality and quantity of the DNA was checked using $2.0 \%$ agarose gel electrophoresis in comparison with known $\lambda$ DNA concentrations. DNA concentrations were also determined using a spectrophotometer (NanoDrop, Wilmington, DE, USA). Portions of the isolated DNA were diluted in molecular grade water to $10 \mathrm{ng} / \mu \mathrm{L}$ concentration and used as templates for subsequent PCR.

\section{SSR PCR amplification}

Thirteen SSR primer combinations from Billotte et al. (2004) and four from Akkak et al. (2009) were used. The 17 SSR primers were accessed from Sigma Aldrich (Castle Hill, NSW, Australia) and are listed in supplementary Table 2). PCR were performed on $10 \mu \mathrm{L}$ volumes of reaction mixture containing 10 ng of genomic DNA, 1 time GoTaq PCR buffer (Promega), $0.5 \mu \mathrm{M}$ forward primer (labeled with M13) and $0.5 \mu \mathrm{M}$ reverse primer, $0.2 \mathrm{mM}$ dNTPs, $0.05 \mu \mathrm{M}$ IRDye 700 or IRDye $800,0.5$ unit Taq DNA polymerase (GoTaq, Promega) and $2.0 \mathrm{mM} \mathrm{MgCl}{ }_{2}$. The 19 base pair M13 sequence (CACGACGTTGTAAAACGAC) was 5'-tailed with all the forward primers. DNA accessions 1 to 41 used IRDye 700 while accessions 42 to 82 used IRDye 800 . The PCR program had an initial hot start at $95^{\circ} \mathrm{C}$ for $3 \mathrm{~min}, 35$ cycles of denaturation at $94^{\circ} \mathrm{C}$ for $30 \mathrm{~s}$, annealing at $45-50^{\circ} \mathrm{C}$ for $30 \mathrm{~s}$, and extension at $72^{\circ} \mathrm{C}$ for $2 \mathrm{~min}$, after which there was a final extension at $72^{\circ} \mathrm{C}$ for $5 \mathrm{~min}$ before the program was terminated by holding at $8^{\circ} \mathrm{C}$. The reaction was performed in a Bio-Rad $\mathrm{T} 100^{\mathrm{TM}}$ Thermal Cycler using $0.2 \mathrm{ml}$ tubes or 96-well plates. Three $\mu \mathrm{L}$ of the PCR product was separated by $2.0 \%$ agarose gel electrophoresis to check the presence of specific bands. Gels were post-stained with GelRed (Biotium) for $15-20 \mathrm{~min}$ and photographed using BIO-RAD Gel Doc ${ }^{\mathrm{TM}}$ XR+ with Imaging Lab ${ }^{\mathrm{TM}}$ Software. Due to the different characteristics between the IRDye 700 and IRDye $800,15 \mu \mathrm{L}$ dye $(0.5 \%$ Fuchsin dye $+100 \%$ formamide $+0.5 \mathrm{M}$ EDTA) was added to PCR samples 1 to 41 , and $10 \mu \mathrm{L}$ to accessions 42 to 82 for optimizing band pattern images shown on the LI-COR machine. All PCR samples were denatured at $94^{\circ} \mathrm{C}$ for $5 \mathrm{~min}$, and the plate was placed on ice before loading. The polyacrylamide gel solution included $20 \mathrm{ml} \mathrm{KB}$ Plus 6.5\% Gel Matrix, $150 \mu \mathrm{L}$ APS (ammonium persulfate solution) and $25 \mu \mathrm{L}$ TEMED (tetramethyl-enediamine). A LI-COR DNA Analyzer Model 4300 for SSR markers was used using SAGA ${ }^{\mathrm{GT}}$ software to image the band pattern for each primer.

All 17 SSR loci were evaluated for amplification on five wild palm accessions, namely $P$. canariensis, $P$. reclinata, $P$. roebelenii, and $P$. theophrasti. These were chosen because of their genetic diversity and importance in breeding programs as they are cross compatible with Phoenix dactylifera and produce fertile hybrid offspring. Procedures for sample collection, DNA isolation, PCR amplification and detection of SSR profiles were as described above for $P$. dactylifera.

\section{Data scoring and analysis}

PCR was performed three times for each primer to confirm band pattern consistency. DNA bands were sized and scored by Image Lab ${ }^{\mathrm{TM}}$ Software and carefully checked manually. Only clear bands were scored and faint bands were ignored. For SSR PCR fragment scoring, each primer was treated as a locus and the number of bands generated from each primer was scored as the number of alleles. Bands with the same size were assumed to represent a single locus. For each locus, data were recorded using ' 1 ' for presence of a band and ' 0 ' for absence to build a binary matrix.

Summary statistics for each group of accessions related to allelic richness, heterozygosity, genetic diversity, number of alleles and Shannon's Information Index were computed using GenAIEx 6.5 (Peakall and Smouse, 2012). Shannon's Information Index was calculated following the method of Lewontin (1972) method. GenAIEx 6.5 was also used to perform principal coordinate analysis (PCoA).

A dendrogram for phylogenetic reconstruction was constructed using a Dice genetic similarity coefficient and the unweighted pair-group method with arithmetic averages (UPGMA) (Nei and Li, 1979). The matrix data in the Excel file were transformed into a Fasta format file, and were imported into MEGA7.0.14 software (Kumar et al., 2016). To evaluate the relative robustness of the groups established in the parsimony analysis, 1000 bootstrap replicates (Felsenstein, 1985) were calculated for dendrogram construction.

The genotype data for the 17 SSR markers were analyzed using a model-based program STRUCTURE V2.3.4 (Pritchard et al., 2000) in order to infer population structure and to assign date palm accessions to different groups. The optimal number of groups was determined by running an admixture and related frequency model with the range of groups from the value of $\mathrm{K}$ (the putative number of populations) from 1 to 10 (ten runs at each $\mathrm{K}$ ). Each run consisted of a burn-in period of 10,000 steps followed by 50,000 Monte Carlo Markov Chain (MCMC) simulations. The most likely $\mathrm{K}$ value for choice was performed by calculating the estimated log probability of data $[\mathrm{LnP}(\mathrm{D})]$ and an ad hoc statistic $\Delta \mathrm{K}$ according to the rate of change in LnP(D) between successive K-values (Evanno et al., 2005). The computation was performed using the STRUCTURE HARVESTER program (Earl and vonHoldt, 2012). Among all 10 independent runs, the one with the highest $\operatorname{Ln} \operatorname{Pr}(\mathrm{X} \mid \mathrm{K})$ value (log probability or $\log$ likelihood) was chosen and represented as bar plots. The resultant population structure of 6 groups was supported by the phylogenetic study (Figure 3) and the model based clusters (Figure 4).

\section{Conclusion}

Florescence-labelled SSR markers were used to investigate the genetic relationships among Australian date palm germplasm and cultivars collected from Iraq and Jordan. A high level of genetic variability was observed among these date palm accessions. Species boundaries were not distinct as two accessions of $P$. theophrasti from Crete clustered with $P$. dactylifera based on SSR analysis. The SSR marker system used in this study was effective in determining the genetic diversity and population structure of date palm. Within the species $P$. dactylifera, the SSR system grouped the cultivated date palm accessions into clusters according to locality and sexuality thus providing valuable information for the future genetic improvement of Australian date palm. SSR markers could be used in future to demonstrate the relationships between molecular markers and important morphological traits, especially those that relate to pest, disease and drought resistance. This could increase the environmental adaptability of date palm cultivars derived from sexual reproduction. However, this study is based on a few randomly selected molecular markers that identified genetic diversity among these cultivars. These markers did not cover the whole genome and genome based sequencing will be required to confirm these findings. 


\section{Acknowledgements}

This project was part of a $\mathrm{PhD}$ research project undertaken at the Plant Breeding Institute - Cobbitty, University of Sydney. The authors thank the Iraqi government for their financial support. We also thank Steve Brauer from Riverland Date Garden, The Desert Fruit Company, Leppington Speedy Seedlings, and Hani Ghnaim from the National Center for Agricultural Research and Extension in Jordan for providing most of the date palm cultivars. We greatly appreciate the help of Mohammed Haraz in collecting samples from Iraq. Our thanks are also due to Simon Goodwin from the Royal Botanic Gardens and Domain Trust for providing samples of the other accessions and to Professor Emeritus R. A. McIntosh and Chongmei Dong for assistance in the preparation of the manuscript.

\section{References}

Abdulla M, Gamal O (2010) Investigation on molecular phylogeny of some date palm (Phoenix dactylifra L.) cultivars by protein, RAPD and ISSR markers in Saudi Arabia. Aust J Crop Sci. 4: 23-28.

Adawy S, Hussein E, Ismail, S, El-Itriby HA (2005) Genomic diversity in date palm (Phoenix dactylifera L.) as revealed by AFLPs in comparison to RAPDs and ISSRs. Arab J Biotech. 8: 99-114.

Ahmad M, Ali N (1960) Effect of different pollens on the physical and chemical characters and ripening of date fruit. Punjab Fruit J. 23: 10-11.

Ahmed TA, Al-Qaradawi AY (2009) Molecular phylogeny of Qatari date palm genotypes using simple sequence repeats markers. Biotechnol. 8: 126-131.

Akbari M, Razavizadeh R, Mohebbi GH, Barmak A (2012) Oil characteristics and fatty acid profile of seeds from three varieties of date palm (Phoenix dactylifera) cultivars in Bushehr-Iran. Afr J Biotechnol. 11: 12088-12093.

Akkak A, Scariot V, Marinoni DT, Boccacci P, Beltramo C, Botta R (2009) Development and evaluation of microsatellite markers in Phoenix dactylifera L. and their transferability to other Phoenix species. Biol Plant. 53: 164166.

Al-Dous EK, George B, Al-Mahmoud ME, Al-Jaber MY, Wang H, Salameh YM, Al-Azwani EK, Chaluvadi S, Pontaroli AC, DeBarry J, Arondel V, Ohlrogge J, Saie IJ, Suliman-Elmeer KM, Bennetzen JL, Kruegger RR, Malek JA (2011) De novo genome sequencing and comparative genomics of date palm (Phoenix dactylifera). Nat Biotechnol. 29: 521-527.

Al-Khalifah NS, Askari E (2003) Molecular phylogeny of date palm (Phoenix dactylifera L.) cultivars from Saudi Arabia by DNA fingerprinting. Theor Appl Genet. 107: 1266-1270.

Al-Mssallem IS (1996) Date palm. Arabian Global Encyclopedia 7: 182-187.

Al-Najm A, Luo S, Ahmad NM, Trethowan R (2016) Molecular variability and genetic relationships of Date Palm (Phoenix dactylifera L.) cultivars based on interprimer binding site (iPBS) markers. Aust J Crop Sci. 10: 732-740.

Al-Ruqaishi IA, Davey M, Alderson P, Mayes S (2008) Genetic relationships and genotype tracing in date palms (Phoenix dactylifera L.) in Oman, based on microsatellite markers. Plant Genet Resour-C. 6: 70-72.

Al-Yahyai R, Al-Khanjari S (2008) Biodiversity of date palm in the Sultanate of Oman. Afr J Agric Res. 3: 389-395.
Allen WJ (1910) The date palm. Agricultural Gazette of N.S.W. 21: 887-889.

Arabnezhad H, Bahar M, Mohammadi HR, Latifian M (2012) Development, characterization and use of microsatellite markers for germplasm analysis in date palm (Phoenix dactylifera L.). Sci Hortic. 134: 150-156.

Barrow S (1998) A monograph of Phoenix L. (Palmae: Coryphoideae). Kew Bull. 53: 513-575.

Barrow S (1999) Systematic studies in Phoenix L. (Palmae : Coryphoideae), In: Henderson A, Borchsenius F (Eds.), Evolution, Variation, and Classification of Palms. The New York Botanical Garden Press, pp. 215-223.

Bashah M (1996) Date variety in the Kingdom of Saudi Arabia, In: King Abdul Aziz University Guidnce Booklet Palms and Dates. King Abdul Aziz Univ. Press, Riyadh, Saudi Arabia, p 1225-1319.

Billotte N, Marseillac N, Brottier P, Noyer JL, JacquemoudCollet JP, Moreau C, Couvreur T, Chevallier MH, Pintaud JC, Risterucci AM (2004) Nuclear microsatellite markers for the date palm (Phoenix dactylifera $\mathrm{L}$.): characterization and utility across the genus Phoenix and in other palm genera. Mol Ecol Notes. 4: 256-258.

Borna F, Luo S, Ahmad NM, Trethowan R (2016) Genetic diversity in populations of the medicinal plant Leonurus cardiaca L. revealed by inter-primer binding site (iPBS) markers. Genet Resour Crop Evol. 64: 342-358.

Cao BR, Chao CCT (2002) Identification of date cultivars in california using AFLP markers. HortScience. 37: 966-968.

Corniquel B, Mercier L (1994) Date palm (Phoenix dactylifera L.) cultivar identification by RFLP and RAPD. Plant Sci. 101: 163-172.

Earl DA, vonHoldt BM (2012) Structure harvester: a website and program for visualizing structure output and implementing the Evanno method. Conserv Genet Resour. 4: 359-361.

El-Assar AM, Krueger RR, Devanand PS, Chao CCT (2005) Genetic analysis of Egyptian date (Phoenix dactylifera L.) accessions using AFLP markers. Genet Resour Crop Evol. 52: 601-607.

Elassar AM, Krueger RR, Devanand PS, Chao CT (2003) Genetic analyses of date palms (Phoenix dactylifera L.) from Egypt using fluorescent-AFLP markers. HortScience 38: 733-734.

Elhoumaizi MA, Devanand PS, Fang JG, Chao CCT (2006) Confirmation of 'Medjool' date as a landrace variety through genetic analysis of 'Medjool' accessions in Morocco. J Am Soc Hort Sci. 131: 403-407.

Elmeer K, Sarwath H, Malek J, Baum M, Hamwieh A (2011) New microsatellite markers for assessment of genetic diversity in date palm (Phoenix dactylifera L.). 3 Biotech. 1: 91-97.

Elsafi M (2012) Study on the on-farm diversity of local date palm (Phoenix dactylifera L.) genetic resources grown in Northern region of Sudan., Department of Plant Breeding and Biotechnology. Swedish University of Agricultural Sciences, p. 66.

Elshibli S, Korpelainen H (2008) Microsatellite markers reveal high genetic diversity in date palm (Phoenix dactylifera L.) germplasm from Sudan. Genetica 134: 251260.

Elshibli S, Korpelainen H (2009) Excess heterozygosity and scarce genetic differentiation in the populations of Phoenix dactylifera L.: human impact or ecological determinants. Plant Genet Resour-C. 7: 95-104.

Elshibli S, Korpelainen H (2010) Identity of date palm (Phoenix dactylifera L.) germplasm in Sudan: from 
morphology and chemical characters to molecular markers, In: Bassil NV, Martin R (Eds.), Acta Hortic. pp. 143-153.

Evanno G, Regnaut S, Goudet J (2005) Detecting the number of clusters of individuals using the software STRUCTURE: a simulation study. Mol Ecol. 14:2611-2620.

FAOSTAT (2012) http://faostat3.fao.org/browse/Q/*/E, accessed 20 May 2015.

Felsenstein J (1985) Confidence limits on phylogenies: an approach using the bootstrap. Evolution 39:783-791.

Ghaleb HHA (2008) Date palm cultivars atlas of United Arab Emirates. In: Ghaleb HHA (ed) Zayed Center for Heritage and History Publications, Al-Ain, UAE.

Gros-Balthazard M (2013) Hybridization in the genus Phoenix: a review. EJFA. 25:831-842.

Hamza H, Abederrahim MAB, Elbekkay M, Ferchichi A (2013) Comparison of the effectiveness of ISSR and SSR markers in determination of date palm (Phoenix dactylifera L.) agronomic traits. Aust J Crop Sci. 7: 763-769.

Hamza H, Benabderrahim MA, Elbekkay M, Ferdaous G, Triki T, Ferchichi A (2012) Investigation of genetic variation in Tunisian date palm (Phoenix dactylifera L.) cultivars using ISSR marker systems and their relation with fruit characteristics. Turkish J Biol. 36: 449-458.

Hamza H, Elbekkay M, Ben Abederrahim MA, Ali AF (2011) Molecular and morphological analyses of date palm (Phoenix dactylifera L.) subpopulations in southern Tunisia. Span J Agric Res. 9: 484-493.

Hussein E, Adawy S, Ismail S, El-Itriby H (2005) Molecular characterization of some Egyptian date palm germplasm using RAPD and ISSR markers. Arab J Biotech. 8: 83-98.

Ibrahim AO (2008) Date palm, the tree of life. Arab centre for the study of arid zones and dry lands. Damascus, Syria.

Jaradat AA, Zaid A (2004) Quality traits of date palm fruits in a center of origin and center of diversity. J Food Agric Environ. 2: 208-217.

Kenna G, Mansfield J (1997) Evaluation of Date Production in Central Australia. RIRDC Project DNT-11A Final Report.

Khan S, Bi TB (2012) Direct shoot regeneration system for date palm (Phoenix dactylifera $\mathrm{L}$.) cv. Dhakki as a means of micropropagation. Pakistan J Bot. 44: 1965-1971.

Khanam S, Sham A, Bennetzen JL, Aly MAM (2012) Analysis of molecular marker-based characterization and genetic variation in date palm (Phoenix dactylifera L.). Aust J Crop Sci. 6: 1236-1244.

Khierallah HSM, Bader SM, Baum M, Hamwieh A (2011) Genetic diversity of Iraqi date palms revealed By microsatellite polymorphism. J Am Soc Hort Sci. 136: 282287.

Krueger RR (1995) Mystique of the date palm links old and new worlds. Diversity 11: 128-129.

Kumar S, Stecher G, Tamura K (2016) MEGA7: molecular evolutionary genetics analysisversion 7.0 for bigger datasets. Mol Biol Evol. doi: 10.1093/molbev/msw054.

Lewontin RC (1972) The apportionment of human diversity. J Evol Biol. 6: 381-392.

Luo S, Goikoetxea Arango A, Mehmood A, Ahmad NM, Brown G (2015) Developing new cordylines via interspecific hybridisation of the Australian native Cordyline stricta with the New Zealand natives $C$. australis and cultivar 'Red Fountain ' (C. hybrida). Proc.VIII IS on New Ornamental Crops \& XII Intl. Protea Research Symp. Eds.: Gollnow B and McConchie R. Acta Hortic. 1097: 205-212.
Mahmud TH (1958) Processing and marketing aspects of the date industry in Coachella Valley, California. Master of Arts thesis in Geography. University of California Los Angeles, P289.

McColl CR (1992) Central Australia date industry: A strategy for development. Department of Primary Industry and Fisheries.

McCubbin MJ (2007) The South African date palm industry strengths and weakness. Acta Hort. 736: 59-63.

Mehmood A, Jaskani MJ, Khan IA, Ahmad S, Ahmad R, Luo S, Ahmad NM (2014) Genetic diversity of Pakistani guava (Psidium guajava L.) germplasm and its implications for conservation and breeding. Sci Hortic. 172: 221-232.

Mehmood A, Jaskani MJ, Saeed A, Rashid A (2013) Evaluation of genetic diversity in open pollinated guava by iPBS primers. Pak J Agr Sci. 50: 591-597.

Mehmood A, Luo S, Ahmad NM, Dong C, Mahmood T, Jaskani MJ, Awan FS, Sharp P (2016) Molecular variability and genetic structure of guava (Psidium guajava L.) cultivars based on inter-primer binding site (iPBS) and microsatellite (SSR) markers. Genet. Resour. Crop Evol. doi: 10. 1007/s 10722-015-0322-7.

Nei M, Li WH (1979) Mathematical-model for studying genetic-variation in terms of restriction endonucleases. Proc Natl Acad Sci. U.S.A. 76: 5269-5273.

Nixon RW (1951) The date palm: "Tree of life" in the subtropical deserts. Econ Bot. 5: 274-301.

Odong TL, Heerwaarden J, Jansen J, Hintum TJL, Eeuwijk FA (2011) Determination of genetic structure of germplasm collections: are tradtional hierarchical clustering methods appropriate for molecular marker data? Theor Appl Genet. 123 (2):195-205. doi:10.1007/s00122-011-1576-x.

Osman AMA (1984) The performance of date palms in the Sudan. Acta Hortic. 143:231-237.

Peakall R, Smouse PE (2012) GenAlEx 6.5: Genetic analysis in Excel. Population genetic software for teaching and research-an update. Bioinformatics 28: 2537-2539.

Petherbridge R (1980) The ecologically favourable areas in Australia for potential cultivation of the date palm (Phoenix Dactylifera). Thesis. University of Sydney.

Pintaud J, Zehdi S, Couvreur T, Barrow S, Henderson S, Aberlenc-Bertossi F, Tregear J, Billotte N (2010) Species delimitation in the genus Phoenix (Arecaceae) based on SSR markers, with emphasis on the identity of the date palm (Phoenix dactylifera L.). Arhus University Press, Denmark.

Pritchard JK, Stephens M, Donnelly P (2000) Inference of population structure using multilocus genotype data. Genetics 155: 945-959.

Reilly R, Reilly A, Lewis I (2010) Towards an Australian Date Industry: An overview of the Australian domestic and international date industries, Electronically published by RIRDC in September 2010.

Rhouma-Chatti S, Choulak S, Zehdi-Azzouzi S, Chatti K, Said K (2014) Molecular polymorphism and phylogenetic relationships withinn Tunisian date palm (Phoenix dactylifera L.): Evidence of non-coding trnL-trnF regions of chloroplast DNAs. Sci Hortic. 170: 32-38.

Rivera D, Obon de Castro C, Carreno E, Inocencio C, Alcaraz F, Rios S, Palazon JA, Vazquez L, Laguna E (2008) Morphological systematics of date-palm diversity (Phoenix, Arecaceae) in Western Europe and some preliminary molecular results, In: GroendijkWilders $\mathrm{N}$, Alexander C, vandenBerg RG,Hetterscheid WLA (Eds.), Proceedings of the Fifth International Symposium on the Taxonomy of Cultivated Plants. Wageningen, Netherlands, pp. 97-104. 
Saker MM, Adawy SS, Mohamed AA, El-Itriby HA (2006) Monitoring of cultivar identity in tissue culture-derived date palms using RAPD and AFLP analysis. Biol Plant. 50: 198-204.

Saker MM, Bekheet SA, Taha HS, Fahmy AS, Moursy HA (2000) Detection of somaclonal variations in tissue culturederived date palm plants using isoenzyme analysis and RAPD fingerprints. Biol Plant. 43: 347-351.

Sakka H, Baraket G, Dakhlaoui Dkhil S, Zehdi Azouzi S, Salhi-Hannachi A (2013) Chloroplast DNA analysis in Tunisian date palm cultivars (Phoenix dactylifera L.): sequence variations and molecular evolution of trnL (UAA) intron and trnL (UAA) trnF (GAA) intergenic spacer. Sci Hortic. 164: 256-269.

Sedra MH, El-Filali H, Frira D (1993) Study of some phenotypic and agronomic characteristics of fruits of date palm cultivars and clonal selections. Al Awamia, 121-135.

Sedra MH, El-Filali H, Nour S, Boussak Z, Benzine A, Allaoui M (1996) The Moroccan date palm grove: evaluation of the palm patrimony. Fruits (Paris) 51: 247259.

Sedra MH, Lashermes P, Trouslot P, Combes MC, Hamon S (1998) Identification and genetic diversity analysis of date palm (Phoenix dactylifera L.) varieties from Morocco using RAPD markers. Euphytica 103: 75-82.

Shabani F, Kumar L, Taylor S (2012) Climate change impacts on the future distribution of date palms: a modeling exercise using CLIMEX. PLoS ONE 7(10): e48021. doi:10.1371/journal.pone.0048021.

Shafique M, Khan AS, Malik AU, Shahid M, Rajwana IA, Saleem BA, Amin M, Iftikhar A (2011) Influence of pollen source and pollination frequency on fruit drop, yield and quality of date palm (Phoenix dactylifera L.) cv. Dhakki. Pak J Bot. 43: 831-839.

Soliman SS, Ali BA, Ahmed MMM (2003) Genetic comparisons of Egyptian date palm cultivars (Phoenix dactylifera L.) by RAPD-PCR. Afr J Biotechnol. 2: 86-87.

Toutain G (1972) Propagation of the date palm. II. Observations on vegetative reproduction of the date palm. Awamia, 81-94.
Trifi M, Rhouma A, Marrakchi M (2000) Phylogenetic relationships in Tunisian datepalm (Phoenix dactylifera $\mathrm{L}$.) germplasm collection using DNA amplification fingerprinting. Agronomie 20: 665-671.

Williams JGK, Kubelik AR, Livak KJ, Rafalski JA, Tingey SV (1990) DNA polymorphisms amplified by arbitrary primers are useful as genetic-markers. Nucleic Acids Res. 18: 6531-6535.

Wrigley G (1995) Date palm (Phoenix dactylifera L.), In: Smartt J, Simmonds NW (Eds.), Evolution of crop plants. Longman, UK, pp. 399-403.

Wünsch A (2009) Cross-transferable polymorphic SSR loci in Prunus species. Sci Hortic. 120:348-352. doi:10.1016/j.scienta.2008.11.012.

Zaid A, de Wet PF (2002) Origin, geographical distribution and nutritional values of date palm. In: Zaid A (Ed.), Date palm cultivation. Food and Agricultural Organisation of the United Nations, Rome, pp. 29- 44.

Zehdi S, Sakka H, Rhouma A, Ould MSA, Marrakchi M, Trifi M (2004) Analysis of Tunisian date palm germplasm using simple sequence repeat primers. Afr J Biotechnol. 3: 215-219.

Zehdi S, Cherif E, Rhouma S, Santoni S, Salhi Hannachi A, Pintaud JC (2012) Molecular polymorphism and genetic relationships in date palm (Phoenix dactylifera L.). The utility of nuclear microsatellite markers. Sci Hortic. 148:255-263.

Zehdi-Azouzi S, Cherif E, Guenni K, Ben Abdelkrim A, Bermil A, Rhouma S, Ben Salah M. Santoni S, Pintaud JC, Aberlenc-Bertossi F, Salhi Hannachi A (2016) Endemic insular and coastal Tunisian date palm genetic diversity. Genetica 144: 181-190.

Zehdi-Azouzi S, Cherif E, Moussouni S, Gros-Balthazard M, Abbas Naqvi S, Ludena B, Castillo K, Chabrillange N, Bouguedoura N, Bennaceur M, Si-Dehbi F, Abdoulkader S, Daher A, Terral JF, Santoni S, Ballardini M, Mercuri A, Salah MB, Kadri K, Othmani A, Littardi C, Salhi-Hannachi A, Pintaud JC, Aberlenc-Bertossi F (2015) Genetic structure of the date palm (Phoenix dactylifera L.) in the Old World reveals a strong differentiation between eastern and western populations. Ann Bot. 116:101-112. 